\title{
HUBUNGAN ANTARA KARAKTERISTIK REMAJA DENGAN RISIKO PENYAKIT HIV-AIDS
}

Teresia Widya Ningsih

IIK STRADA INDONESIA

Teresiawidya151199@gmail.com

\begin{abstract}
Abstrak
Salah satu fase yang mempunyai kerentanan yang tinggi terhadap penularan HIV-AIDS adalah masa remaja, suatu masa yang mempunyai mobilitas sosial yang paling tinggi dibandingkan masa usia lainnya. Pada tahun terakhir ini terdapat kecenderungan peningkatan kasus penyakit HIV-AIDS khususnya pada kelompok remaja yang merupakan usia reproduktif. Rendahnya pengetahuan HIV/AIDS dikalangan remaja mempengaruhi sikap remaja pada prilaku seksual pranikah sehingga dapat meningkatkan kerentanan remaja untuk tertular HIV/AIDS. Upaya pencegahan dilakukan melalui pendidikan dan penyuluhan masyarakat terutama ditujukan pada populasi berisiko yang mudah menyebarkan penyakit.
\end{abstract}

Kata Kunci: HIV, AIDS, Remaja

\section{LATAR BELAKANG}

Remaja dalam perkembangannya memerlukan lingkungan adaptif yang menciptakan kondisi yang nyaman untuk bertanya dan membentuk karakter bertanggung jawab terhadap dirinya. Ada kesan pada remaja, seks itu menyenangkan, puncak rasa kecintaan, yang serba membahagiakan sehingga tidak perlu ditakutkan. Berkembang pula opini seks adalah sesuatu yang menarik dan perlu dicoba (sexpectation). Terlebih lagi ketika remaja tumbuh dalam lingkungan mal-adaptif, akan mendorong terciptanya perilaku amoral yang merusak masa depan remaja. Dampak pergaulan bebas mengantarkan pada kegiatan menyimpang seperti seks bebas, tindak kriminal termasuk aborsi, narkoba, serta berkembangnya penyakit menular seksual (PMS) (Arma, 2008) 
Masalah yang berkaitan dengan perilaku dan reproduksi remaja seperti bertambahnya kasus penyakit menular seksual terutama HIV-AIDS, kematian ibu muda yang masih sangat tinggi, merebaknya praktik aborsi karena kehamilan yang tidak diinginkan dan kecenderungan remaja masa kini untuk melakukan hubungan seksual sebelum nikah. Perilaku seks pranikah ini memang kasat mata, namun ia tidak terjadi dengan sendirinya melainkan didorong atau dimotivasi oleh faktor internal yang tidak dapat diamati secara langsung (tidak kasat mata). Dengan demikian individu tersebut tergerak untuk melakukan perilaku seks pranikah. Banyaknya orang tua yang kurang mengawasi pergaulan anak dan kurangnya kasih sayang orang tua bisa menjadi penyebab utama seorang remaja menjadi salah pergaulan dan terjerumus pada hal-hal negatif salah satunya seks bebas. Seks bebas bisa menjadi pemicu penyakit HIV-AIDS (Yuliantini, 2012).

\section{Human Immunodeficiency}

Virus atau HIV adalah virus yang menyerang sel darah putih di dalam tubuh (limfosit) yang mengakibatkan turunnya kekebalan tubuh manusia.
Orang yang dalam darahnya terdapat virus HIV dapat tampak sehat dan belum tentu membutuhkan pengobatan. Meskipun demikian, orang tersebut dapat menularkan virusnya kepada orang lain bila melakukan hubungan seks berisiko dan berbagi penggunaan alat suntik dengan orang lain. Acquired Immune Deficiency Syndrome atau AIDS adalah sekumpulan gejala penyakit yang timbul karena kekebalan tubuh yang menurun yang disebabkan oleh infeksi HIV. Akibat menurunnya kekebalan tubuh pada seseorang maka orang tersebut sangat mudah terkena penyakit seperti TBC, kandidiasis, berbagai radang pada kulit, paru, saluran penernaan, otak dan kanker (KPAD Kab. Jember, 2015).

Menurut data Kemenkes RI (2015), pada tahun 2010-2012 Jumlah kasus baru HIV positif di Indonesia cukup stabil, kemudian pada tahun 2013 dan 2014 kembali mengalami peningkatan secara signifikan. Pada tahun 2010 jumlah kasus baru HIV positif sebesar 21.591 kasus kemudian meningkat secara signifikan pada tahun 2014 yaitu sebesar 32.711 kasus baru. 
Peningkatan jumlah kasus baru AIDS selalu terjadi setiap tahunnya, hingga puncaknya pada tahun 2013 tercatat 10.163 kasus kemudian terjadi penurunan jumlah kasus baru pada tahun 2014 yaitu sebesar 5.494 kasus dengan jumlah kumulatif kasus AIDS sampai dengan akhir 2014 sebesar 65.790 kasus (Kemenkes, 2015).

\section{KASUS/MASALAH}

Apa hubungan karakteristik remaja dengan resiko penyakit HIV-AIDS?

\section{TINJAUAN PUSTAKA}

\section{A. Pengertian HIV}

\section{HIV}

(Human

Immunodeficiency Virus) adalah sejenis virus yang menyerang sistem kekebalan tubuh manusia dan dapat menimbulkan Acquired Immuno Deficiency Syndrome (AIDS). HIV menyerang salah satu jenis dari sel-sel darah putih yang bertugas menangkal infeksi. Sel darah putih tersebut terutama limfosit yang memiliki CD4 sebagai sebuah marker atau penanda yang berada di permukaan sel limfosit. Karena berkurangnya nilai CD4 dalam tubuh manusia menunjukkan berkurangnya sel-sel darah putih atau limfosit yang seharusnya berperan dalam mengatasi infeksi yang masuk ke tubuh manusia. Pada orang dengan sistem kekebalan yang baik, nilai CD4 berkisar antara 1400-1500. Sedangkan pada orang dengan sistem kekebalan yang terganggu (misal pada orang yang terinfeksi HIV) nilai CD4 semakin lama akan semakin menurun (bahkan pada beberapa kasus bisa sampai nol) (Ajik, 1999).

Virus HIV diklasifikasikan ke dalam golongan lentivirus atau retroviridae. Virus ini secara material genetik adalah virus RNA yang tergantung pada enzim reverse transcriptase untuk dapat menginfeksi sel mamalia, termasuk manusia, dan menimbulkan kelainan patologi secara lambat. Virus ini terdiri dari 2 grup, yaitu HIV-1 dan HIV-2. Masing-masing grup mempunyai lagi berbagai subtipe, dan masing-masing subtipe secara evolusi yang cepat mengalami mutasi. Diantara kedua grup tersebut, yang paling banyak menimbulkan kelainan dan lebih ganas di seluruh dunia adalah grup HIV-1 (KPAD Kab. Jember, 2015).

\section{B. Pengertian AIDS}


Acquired Immune Deficiency

Syndrome atau AIDS adalah sekumpulan gejala penyakit yang timbul karena kekebalan tubuh yang menurun yang disebabkan oleh infeksi HIV. Akibat menurunnya kekebalan tubuh pada seseorang maka orang tersebut sangat mudah terkena penyakit seperti $\mathrm{TBC}$, kandidiasis, berbagai radang pada kulit, paru, saluran penernaan, otak dan kanker. Peningkatan jumlah kasus baru AIDS selalu terjadi setiap tahunnya, hingga puncaknya pada tahun 2013 tercatat 10.163 kasus kemudian terjadi penurunan jumlah kasus baru pada tahun 2014 yaitu sebesar 5.494 kasus dengan jumlah kumulatif kasus AIDS sampai dengan akhir 2014 sebesar 65.790 kasus (Kemenkes, 2015).

\section{Pencegahan Hiv dan Aids}

Upaya preventif terkait pelayanan kesehatan HIV dan AIDS dapat dilakukan melalui peningkatan gaya hidup sehat, memahami bahaya, dan pencegahannya melalui tindakan asertif dari penyakit HIV-AIDS. Tindakan asertif adalah suatu kemampuan untuk mengomunikasikan hal yang diinginkan kepada orang lain, namun tetap menjaga dan menghargai orang tersebut. Sikap asertif menuntut seseorang untuk konsisten dan jujur dalam mengespresikan perasaan, pendapat, dan kebutuhan secara sadar tanpa memanipulasi. Pencegahan HIV dan AIDS dapat dilakukan melalui konsep pendekatan $\mathrm{ABCD}$, yaitu A (Abstinence) artinya absen seks atau tidak melakukan hubungan seks bagi orang yang belum menikah; B (Faithful) artinya bersikap setia kepada satu pasangan seksual (tidak berganti pasangan seks); C (Condom) artinya cegah penularan HIV melalui penggunaan kondom; dan D (Drug) artinya tidak menggunakan narkoba (Niniek Lely Pratiwi, 2011)

Dalam hal ini, perguruan tinggi dapat melakukan kerja sama lintas sektoral dengan pihak terkait (Dinas Kesehatan dan Komisi Penggulangan HIV/ AIDS di masingmasing wilayah) untuk memberikan informasi yang benar mengenai HIV/ AIDSdi lingkungan keluarga, khususnya pada pasangan suami dan istri. Hal ini penting sebagai upaya untuk mengurangi persepsi negatif atau stigma pada individu dan keluarga. Peran pencegahan HIV/ AIDS dapat ditingkatkan melalui 
upaya peningkatan kewaspadaan individu dan keluarga untuk melakukan pencegahan ABCD sehingga penularan HIV/ AIDS dapat dicegah. Sebagai rekomendasi, diperlukan strategi pendekatan sosialisasi dan pemberian informasi berbasis gender untuk mencapai kewaspadaan penularan HIV/ AIDS terkait upaya peningkatan pengetahuan dan penurunan stigma (Arifin, 2006).

\section{PEMBAHASAN}

Hubungan seks pranikah tidak hanya belum diterima oleh masyarakat tetapi juga menimbulkan masalah lain. Kehamilan di luar nikah adalah salah satu masalah yang muncul akibat hubungan seks sebelum nikah. Kehamilan ini tidak saja menimbulkan masalah sosial, tetapi juga masalah kesehatan bagi yang bersangkutan, terutama bila yang mengalaminya adalah remaja yang masih muda usia. Kehamilan pada usia muda ditinjau dari segi kesehatan mengandung risiko tinggi, baik ketika masa kehamilan maupun saat melahirkan. Risiko tinggi yang dimaksud bukan hanya risiko sakit pada yang mengandung dan dikandung, tetapi juga risiko kematian. Perilaku seks pranikah ini memang kasat mata, namun ia tidak terjadi dengan sendirinya melainkan didorong atau dimotivasi oleh faktor internal yang tidak dapat diamati secara langsung (tidak kasat mata). Dengan demikian individu tersebut tergerak untuk melakukan perilaku seks pranikah (Yuliantini, 2012).

Tindakan remaja yang seringkali tanpa kendali menyebabkan bertambah panjangnya problem sosial yang dialaminya. Menurut WHO, di seluruh dunia, setiap tahun diperkirakan sekitar 4060 juta ibu yang tidak menginginkan kehamilan melakukan aborsi. Setiap tahun diperkirakan 500.000 ibu mengalami kematian oleh kehamilan dan persalinan. Sekitar 30-50\% diantaranya meninggal akibat komplikasi abortus yang tidak aman dan $90 \%$ terjadi di negara berkembang termasuk Indonesia (Ngudi, 2010).

Di sinilah suatu masalah acapkali muncul dalam kehidupan remaja karena mereka ingin mencobacoba segala hal, termasuk yang berhubungan dengan fungsi ketubuhannya yang juga melibatkan pasangannya. Namun dibalik itu 
semua, faktor internal yang paling memengaruhi perilaku seksual remaja sehingga mengarah pada perilaku seksual pranikah pada remaja adalah berkembangnya organ seksual. Dikatakan bahwa gonads (kelenjar seks) yang tetap bekerja (seks primer) bukan saja berpengaruh pada penyempurnaan tubuh (khususnya yang berhubungan dengan ciri seks sekunder), melainkan juga berpengaruh jauh pada kehidupan psikis, moral, dan sosial. Pada kehidupan psikis remaja, perkembangan organ seksual mempunyai pengaruh kuat dalam minat remaja terhadap lawan jenis kelamin.

Pendidikan seks antara khususnya, memerlukan Komunikasi, Informasi, Pendidikan dan Komunikasi (KIE) dengan klan yang benar dan akurat secara efektif melalui pendidikan sebaya secara bersamaan untuk para siswa dan kebutuhan akan informasi tentang kesehatan reproduksi dan penyakit menular seksual (PMS) dalam materi KIE adalah integral dengan pencegahan AIDS. Metode pendekatan pendidikan sebaya dalam konteks respon yang dimaksud adalah berbagai kegiatan yang bertujuan untuk mengembangkan pengetahuan, sikap dan tindakan seseorang atau sekelompok orang yang terkait dengan HIV / AIDS. Pendidikan sebaya dilakukan di antara kelompok sebaya yang dipandu oleh fasilitator yang juga berasal dari kelompok itu sendiri (Sodik, 2018)

Kesulitan yang timbul kemudian adalah apabila pengetahuan orang tua kurang memadai menyebabkan sikap kurang terbuka dan cenderung tidak memberikan pemahaman tentang masalahmasalah seks anak. Akibatnya anak mendapatkan informasi seks yang tidak sehat. Seorang peneliti menyimpulkan hasil penelitiannya sebagai berikut: informasi seks yang tidak sehat atau tidak sesuai dengan perkembangan usia remaja ini mengakibatkan remaja terlibat dalam kasus-kasus berupa konflik dan gangguan mental, ide-ide yang salah dan ketakutan-ketakutan yang berhubungan dengan seks. Dalam hal ini, terciptanya konfl ik dan gangguan mental serta ide-ide yang salah dapat memungkinkan seorang remaja untuk melakukan perilaku seks pranikah (Yuliantini, 2012) 
Seorang remaja yang kurang pengawasan orang tua menjadikan remaja yang salah pergaulan dan rentan mencoba hal-hal baru yang menurutnya menarik. Terkadang remaja juga salah memilih teman, yang malah menjerumuskannya kedalam lingkungan salah. Perilaku yang tidak sesuai dengan tugas perkembangan remaja pada umumnya dapat dipengaruhi orang tua. Bilamana orang tua mampu memberikan pemahaman mengenai perilaku seks kepada anak-anaknya, maka anak-anaknya cenderung mengontrol perilaku seksnya itu sesuai dengan pemahaman yang diberikan orang tuanya (Lestari, 2013)

\section{KESIMPULAN}

1. Diperlukan pengembangan pemberdayaan masyarakat dengan peningkatan pengetahuan tentang upaya pencegahan HIV-AIDS pada kelompok masyarakat, kader kesehatan reproduksi baik melalui para ibu PKK, karang taruna, tokoh agama dan budayawan setempat agar meraka dapat berperan serta sebagai fi gure dalam memberikan keteladanan, sikap, afektif serta paternalistik yang dapat menjadi contoh para remaja agar berperilaku seks yang aman dan sehat untuk upaya pencegahan IMS, HIV-AIDS.

2. Peran orang tua sebagai orang terdekat dan seseorang yang lebih banyak frekuensi untuk bertemu dalam keluarga sangat diperlukan untuk membekali diri pengetahuan tentang upaya pencegahan HIVAIDS pada keluarganya sejak usia dini. Para orang tua juga perlu dibekali bagaimana cara berkomunikasi yang baik dengan putra-putrinya terutama menjelang usia remaja.

\section{DAFTAR PUSTAKA}

Ajik, S. (1999). Pengetahuan Penyakit Menular Seksual (PMS) dan HIV/AIDS Remaja Pekerja PT Flower Indonesia dan Upaya Pencegahannya. Penelitian Sistem Kesehatan, 20-30.

Arifin. (2006). Dampak Stigma dan Diskriminasi terhadap Penanggulangan HIV/AIDS 
di Indonesia. Perhimpunan

Dokter Peduli AIDS Jawa

Timur.

Arma, A. J. (2008). Pengaruh Perubahan Sosial Terhadap Perilaku Seks Remaja. Universitas Sumatera Utara, 189-197.

Lestari, D. H. (2013). Pengembangan Program Pemberdayaan Peningkatan Kemandirian Ibu Rumah Tangga Pengidap HIV. Buletin Penelitian Sistem kesehatan, 283-295.

Ngudi, E. M. (2010). Hubungan Tingkat Pengetahuan Tentang HIV/AIDS pada Mahasiswa Reguler Universitas Indonesia. Journal Endurance, 145-150.

Niniek Lely Pratiwi, H. B. (2011). HUBUNGAN

KARAKTERISTIK REMAJA

TERKAIT RISIKO

PENULARAN HIV-AIDS

DAN PERILAKU SEKS

TIDAK AMAN DI INDONESIA. Surabaya: Universitas Airlangga.

Sodik, M. A. (2018). Analysis of Improved Attitude of Youth in HIV / AIDS Prevention through the Provision of Health Education with Peer Education. The 2nd Joint International Conferences, 495-502.

Yuliantini, H. (2012). Tingkat Pengetahuan HIV/AIDS dan
Sikap Remaja Terhadap Perilaku Seksual PraNikah di SMA "X.". Universitas Indonesia.

Komisi Penanggulangan AIDS Kabupaten Jember. 2015. Mengenal \& Menanggulangi HIV \& AIDS Infeksi Menular Seksual dan Narkoba. Jember: Komisi Penanggulangan AIDS Kabupaten Jember

Kementerian Kesehatan RI. 2015. Profil Kesehatan Indonesia 2014. Jakarta: Kementerian Kesehatan RI. http://www.depkes.go.id/resources/d o wnload/ pusdatin/profilkesehatanindonesia/profilkesehatan-indonesia2014.pdf. [27 Desember 2015]. 